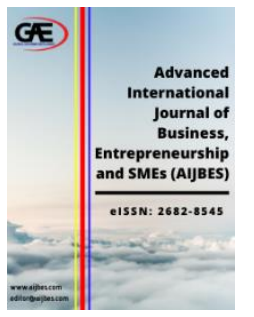

\author{
ADVANCED INTERNATIONAL JOURNAL OF \\ BUSINESS, ENTREPRENEURSHIP AND SMES \\ (AIJBES) \\ WwW.aijbes.com
}

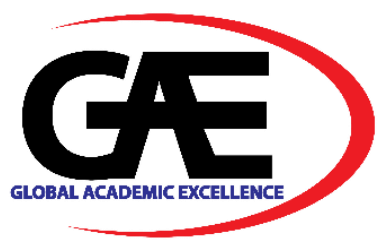

\title{
CONTRIBUTING FACTORS TO SMEs SUCCESS AMONG YOUTH
}

\author{
Nor Azira Ayob ${ }^{1 *}$, Intan Suria $\mathrm{Hamzah}^{2}$, Anis Izzati Romly ${ }^{3}$, Nur Idayuni Mohd Asri ${ }^{4}$, Mohd Amar \\ Aziz $^{5} \&$ Noor Hadzlida Ayob ${ }^{6}$ \\ 1 Faculty of Administrative Science and Policy Studies, Universiti Teknologi MARA (UiTM), Malaysia \\ Email: norazira@uitm.edu.my \\ 2 Department of Social Studies and Citizenship, Human Sciences, Universiti Pendidikan Sultan Idris (UPSI) \\ Email: intan.hamzah@fsk.upsi.edu.my \\ 3 Faculty of Administrative and Policy Studies, Universiti Teknologi MARA (UiTM), Malaysia \\ $4 \quad$ Faculty of Administrative and Policy Studies, Universiti Teknologi MARA (UiTM), Malaysia \\ 5 Faculty of Administrative Science and Policy Studies, Universiti Teknologi MARA (UiTM), Malaysia \\ E-mail: amaraziz@uitm.edu.my \\ 6 Department of Social Studies and Citizenship, Human Sciences, Universiti Pendidikan Sultan Idris (UPSI) \\ * $\quad$ Corresponding Author
}

\section{Article Info:}

\section{Article history:}

Received date: 14.04 .2021

Revised date: 20.04 .2021

Accepted date: 01.05.2021

Published date: 15.06 .2021

\section{To cite this document:}

Ayob, N. A., Hamzah, I. S., Romly, A. I., Asri, N. I. M., Aziz, M. A., \& Ayob, N. H. (2021). Contributing Factors To SMEs Success Among Youth. Advanced International Journal of Business, Entrepreneurship and SMEs, 3 (8), 01-21

DOI: $10.35631 /$ AIJBES.38001.

This work is licensed under $\underline{\mathrm{CC} B Y} 4.0$

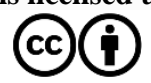

\section{Abstract:}

Youth unemployment is one of the major global challenges for decades to come. While bound up with the overall employment situation, this challenge has its own dimensions and therefore requires specific responses. Unemployment or job difficulties have always been problems, especially for youth as they need to face it once they graduate. The government invents a lot of activities to cope with the unemployment issue in the country by cultivating entrepreneurship in society with a focus on students and youth to transform them to be an entrepreneur. So that this could lessen the problem at an early stage. Therefore, this study aims to identify the factors that contribute to the success of youth in entrepreneurship including business plan, business support program, and risk-taking, and how each of these influences' youth entrepreneurship. The significance of this study is especially for youths include those who may leave their education and started their first jobs. Youth could expose the factors that lead to the effectiveness of the program. Even the youth may come from different fields, this could help them find the job if the current job mismatch with their field or being unemployed. A total of 200 youth respondents were collected from the youths who have become entrepreneurs and youth entrepreneurship has never been to obtain relevant data. The data collected, analyzed using IBM SPSS Statistics. using Non-Probability Sampling and the sample size by Roscoe. Results from this study revealed that all the listed factors contribute to the successfulness of youth to become 
Volume 3 Issue 8 (June 2021) PP. 01-21

DOI 10.35631/AIJBES.38001

entrepreneurs and the most contributing factor to the success of youth in entrepreneurship is Business Support Program.

Keywords:

Youth Entrepreneurs, Successfulness, Business Plan, Business Support Program, Risk Taking

\section{Introduction}

Youth is one of the valuable asset that constitute to the economic development of the country. Thus, youth should be well prepared for their future, as it is important to the course of poverty reduction and growth. In Malaysia, entrepreneurship is one of the main key in order to build success and encourage regional growth among youth, as stated by the most government and local communities across the world. Therefore, Malaysia government is encouraging youth to move towards self-employment as a part of action taken to control the unemployment issues. By promoting youth to join entrepreneurship because it can make the young people understand that they have many ways to create their future path by starting their own business rather than waiting to be employed. The Government are intended to produce more entrepreneurs so that the country could compete with other develop countries until the international level like United Kingdom (UK). This is because small industries in UK growth twice in the $80^{\text {th }}$ era and drastically rise around 1990 (David Deakins, 1999 as cited in Warman, et al., 2010). Such growth is encouraging and should be example for a country especially Malaysia as it can reduce unemployment rate among graduates as what being stated by the government.

With the growing rate of unemployment day by day, the lack of knowledge and awareness on entrepreneurship has become a challenge toward graduated themselves. In order to overcome the problem, the government has come out with several programs and activities to educate and raise awareness about the entrepreneurship to the youth such as the Mobile Entrepreneur Program (Ogilvy, 2018). Beside, having e-entrepreneurship, the government also introduce Program Tunas Usahawan Bumiputera (TUBE) in 2014 with 1,436 participation of youth and 99\% had registered with Suruhanjaya Syarikat Malaysia (SSM). This is the government initiative to help and support entrepreneurs among Bumiputera youth. The goals of the program are to encourage the entrepreneurship spirit among youth, as a paradigm to shift the youth from employee to business owner and to develop the youth with resilience in handling the business. The TUBE program include three phase: Phase 1 - Durability of self-concept of Millitary, Phase 2 - Exposure to Entrepreneurship Knowledge and Phase 3 - Implementation of Business Plan and "Buddy System". Those phases reflect that besides financial support, government also provide non-financial support (through training) (Ministry of Entrepreneur Development, 2017). In order to reduce the unemployment among youth, Malaysian government introduce many programs and initiatives especially in entrepreneurship programs. Based on that issues, the purpose of this study is to evaluate the factors that contribute to successfulness of youth in entrepreneurship.

\section{Literature Review}

The phenomena of rising of unemployment rate among youth is still occurring. According to Rahmah et al. (as cited in Hanapi \& Nordin, 2013) stated that the quality of the graduates is one of the factors that contribute to the unemployment problem among the graduates in Malaysia. There are certain employers complained that the graduates do not have the 
Volume 3 Issue 8 (June 2021) PP. 01-21 DOI 10.35631/AIJBES.38001

appropriate qualifications and skills that meet the needs of industry. Other than that, the issues of unemployment rising due to mismatch of job opportunities and location of worker. Beside unemployment issues, the fact that unemployment rate increasing is due to lack of awareness among youth about entrepreneurship. According Warman et al. (2010), some individuals have backward mentality by stating that entrepreneurship cannot guarantee future because it may not provide better job secure rather than as what they see as being an employee that having daily wages either in public sector nor private sector. The reason behind it because there is lack of education and knowledge in the people itself. Bakar et al. (2016) did mentioned in the study that, for those who does not choose entrepreneurship as their working career stated that they do not poses entrepreneurship quality, reluctant to take risk, no capital to start up the business, focused on family matters and seen entrepreneurship is a fussy thing. This can be supported to the study by Barjayai (2000) where youth are lack of entrepreneurship concept and philosophy thus they tend to not to join entrepreneurship. Referring to Rohaizat (2001), the graduates are not interested in entrepreneurship to be one of their career because lack of financial support, high cost and depression of economy and lack of knowledge that instill in them during business process.

Even though government has come out with various programs among school students created especially for the youth in entrepreneurship, the unemployment rate among youth still increase until now. This problem has negatively affected the economic development (GDP), it decreases the standard of living. Even though in Malaysia achieved full unemployment rate which is less than $4 \%$ as according to International Labor Organization (ILO). According to Bank Negara Malaysia (BNM), the highest global unemployment rate was recorded in 2013 amounting $13.2 \%$ and it stagnant at the highest rate at $13.1 \%$. The unemployment rate among youth in Malaysia was recorded highest in 2015 at $10.7 \%$. In order for government to cope with the rising of unemployment the government should encourage the youth to involved in entrepreneurship. Awareness among youth related to entrepreneurship should be raised so that the youth could knowing the field better. The government should organize program and make sure that it benefits the youth. The factors of successes of the entrepreneurship program plays an important role.

\section{Business Plan}

The first step in developing into a new venture is the entrepreneur usually need to write a business plan. In order to have a successful business, the youth entrepreneurship should have included the business plan. Business plan is a formal document that give details on the opportunity and outlines the tactical approach to go after the opportunity. When they have plan and follow the outline of the strategic and the goals written in the business plan, there is probability they would become successful in their business. Ferreira et al. (2016) found that there are many positive effects from the business plan that stress on the speed in decision making, the expectation on business weakness, and the improvement of communication internal and external to business. Other than that, the business plan also outlines the estimation cost and profitability projections, provide information for potential partners and other investors and also to guide the strategy (Becherer \& Helms, 2009). Frese (2009) stated that business plans also were used to help people maintain, commence, and evaluate the actions needed in order to achieve goal. 
Volume 3 Issue 8 (June 2021) PP. 01-21 DOI 10.35631/AIJBES.38001

However, according to Chandler, Detienne et al. (2011), Delmar and Shane (2003), there is a debate about the value of business plan in the entrepreneurship field. While certain researchers that business plan is a fundamental activity for success in creating a business, the others are questioning about the statement (Gruber, 2007) by taking into consideration of the high levels of uncertainty and volatility in the startup's environment. They are questioning whether business plan is necessary or not since it includes varieties predictions about the future, which is uncertain because it is continually evolving (Becherer \& Helms, 2009).

It is agreed by Karlsson and Honig (2009) that it is not useful to used or updated. They found that six companies over five years are conforming to the business plan at first, but gradually loose coupling with the plans as time passed by. The entrepreneurs who mostly write the business plans also never updated them and rarely referred to it. It is also found that most of the small business did not update their business plan, which it can be assume that they only used it during the early stage of financing. It is said that persistence only is a weak measurement for success. The young entrepreneurs should have identified the possibility to failure earlier and take corrective action so that they would not failed in the business. The entrepreneur should avoid pursuing activities that could bring to failure and unnecessary resources expenditures (Honig \& Samuelsson, 2011).

Some scholarship proposed that doing the business planning would interfere with efforts of timeconstrained entrepreneurs to manage more effective activities in the nascent process (Ansoff, 1991; Bhide, 2000; Sarasvathy, 2001; Gruber, 2007; Honig, 2004). It is argued that planning would give fake illusion of controls and potentially could give harmful forecasts because of the incapacity to gather and analyze information about the future (Honig, 2004; Sarasvathy, 2001).

\section{Business Support Program}

In order to study factors affecting the youth entrepreneurship, it is necessary to understand the business support program, which much related to business advisory service or business assistance, that mainly come from the government side. An infant firm or Small Medium Enterprises (SMEs) should has be given out the support, because it is still new and not much stable in the field. This is because an entrepreneur might not be able to barely express out what is their needed due to difference business field acquire different need. According to Harper (2011), business support services is a support services that used and bought by the business excluding financial. Meanwhile, Mole (2002) explained the concept of the business support services is a government approach to provide assistance, to promote, to improve and provide training to mostly small and medium enterprises (SMEs). Business support service mainly focused on giving assistance to SMEs by the government and other institutions or agencies whether through training, mentoring or advising so that it could be backbone to improve and expand the business toward a stable enterprise.

Research done by Yusoff and Yaacob (2010) stated that one of the initiatives taken by the government to help the entrepreneur is through the introducing a service namely government business support services or known as GBSS. The government may support in term of financial or non-financial. GBSS also one of the business advisor, which characterized a person that own several of skills and knowledge, related to certain field especially business performance as mentioned by Schaper and Vollery (as cited in Yusoff and Yaacob, 2010). Therefore, Stanger 
Volume 3 Issue 8 (June 2021) PP. 01-21 DOI 10.35631/AIJBES.38001

(2004) defined business advisor as an individual or organization that serve service as business consultation either verbally or written in relation to tax compliances, preparation of financial statement, law financing, operation and financial management.

In general, both definition refer business advisor is someone that providing service to business owner due to capability and expertise in business for the better business operation. The GBSS give lot of impact towards SMEs in the development of the business operation as it acts as the backbone to it (Yusoff \& Yaacob, 2010). In order to be a successful entrepreneur, once must get the support from government as a start up to the business because, through the government help, the entrepreneur may get what are necessary towards their business in order to cover the loop hole in the business.

Moreover, according Mohd Khanet et al. (2016), to ensure that support programs meet the entrepreneur satisfaction, policy makers and programs administrator have to measure satisfaction of business support program through the impact on performance, growth in sales, employment and profitability. To do such measurement, the party that responsible to carry out the task is government, in which government may provide all the aids in order to help this infant firm or SMEs. Meanwhile, SMEs get no support from government in any business program in the early independence until industrialization era in 1960 (Ismail \& Othman (2014). However, during the 1960, government finally include some sort of SMEs assistance in First Malaysian Plan (1966-1970). After finding out SMEs could contribute to nation economy, various programs and incentives were introduced which known as government-support programmes (GSPs). This programmes focused on giving effective assistance regarding training, financial and marketing.

Besides, in helping the SMEs or new business to carry on with the operation of the business, again, government assistance seems to be a tool that assist business from failure yet help to compete in the open market until the SMEs able to maintain it performance in the future (Ahmad \& Abd Latif, 2012). A study conducted by Yusuf (2010) found that creating a new business operation is crucial for the entrepreneur to get assistance program because obviously the new entrepreneurs and their start-up organization require some amount of capital with the right estimation amount to be used and frequently external guide and assistance to support their business. In Malaysia, prominent agencies that provide the business assistance services are Small and Medium Enterprise Corporation (SME Corp), Malaysia External Trade Development Corporation (MATRADE), Federal Agriculture Marketing Authority (FAMA), Malaysian Agriculture Research Development Institute (MARDI), Standards and Industrial Research Institute of Malaysia (SIRIM), Department of Veterinary Service (DVS), Malaysia Palm Oil Board (MPOB), People Council of Trust (MARA), Malaysian Productivity Council (MPC) and many more.

After referring to the previous study, Stevenson and Sahlman (1988), Yusuf (2010), Ahmad and Abd Latif (2012), Jauriyah (2015) and Ismail and Othman (2014) found there is positive impact of business support program to the entrepreneur in term of SMEs performance. From their study, effectiveness of the business assistance can be measured by the performance after receiving the aids from the agency. The only way to contribute to the effectiveness assistance program is the entrepreneur need to relinquish whether financially or non-financially in joining 
Volume 3 Issue 8 (June 2021) PP. 01-21

DOI 10.35631/AIJBES.38001

the assistance program. Nevertheless, the study by Park and Ren (2001) did shown negative relationship between business support program and entrepreneur (through SMEs performance).

\section{Risk-Taking}

Entrepreneur is a risk-taker. According to Brockhaus (1980) risk is the perceived probability of receiving the rewards associated with success of a proposed situation, which is required by an individual before he will subject himself to consequence associated with failure, the alternative situation providing less reward as well as less severe consequences than the proposed situation. In point of view of Nicklas (1996) a Sociologist, stated that there is transition of society from traditional to modern which appeared as neologism that reflect the term "risk". The researcher further explained on the transition part: "This it was an ostensible loss from the old rhetoric's Fortuna as content of religious and virtue of prudential in appearing commercial society. Generally, the definition of risk refers to the situation of the unwanted event that having possibility to loss something either it might have happened or otherwise.

As for Akehurst et al. (2012) defined risk in positive view is the ability to emerge in opportunities that seen as possibility of rewards, and in meantime accepting the consequences with failure of such opportunities. According to an academic literature, Knight (1921) as cited in Haan (2010), risk is a subject event which was not possible to specify some numerical probabilities that are known with distribution of probability and degree of uncertainty as it based on event. Forlani and Mullins (2000) support that outcomes of set of behaviors may affected by the potential loss and the degree of uncertainty.

Risk-taking become one of the hallmarks of an entrepreneurial endeavors. Based on the study by Aman and Nakhaei (2011), risk-taking is define as behaviors that involve propensity to face with harmful or dangerous at once become an opportunity towards the outcome, which it can be seen as positive effect. The researcher also stated that entrepreneur is always deal with risks but not every kind of it. The entrepreneur may treat risk as a chance or it can be uncertainty. Therefore, entrepreneurship is a process for entrepreneur to create new jobs and firms in a creative way and the develop organization should be affiliated with risk- taking because this contribute to new product initiation. Aman and Nakhaei (2011) states that since entrepreneur are familiar with risk-taking, there are four type of risk that connected with entrepreneur such as financial risk, job risk, social and family risk and mental risk. All the risk greatly could influence the entrepreneur. Besides, the risk-taking may influenced by risk propensity and risk perception. High-risk propensity and low risk perception will lead to risk decision-making (Salleh \& Ibrahim, 2011).

Personal properties of entrepreneurs are risk-taking. Risk-taking propensity element that may be crucial in making decision to enter an entrepreneurship career or to found a new startup firm and for the small firms' development and success (Antoncic et al., 2012; Gantar et al., 2013). Furthermore, study done by Macko and Tyszka (2009) stated that the tendency of entrepreneur in risk taking much related with risk perception. Risk perception of a situation may be differing for an individual to another where some will consider higher risk in generated factor, while others will evaluate the higher risk factor in the strategic outcome. In order to have high risk propensity, one must put the perception of decision high. Therefore, in riskiness situation, it allows the decision maker to develop some beliefs about the future outcomes during the estimation of the riskiness situation. This belief results from their experiences. 
However, the researcher believed that experience has no control over the outcomes on those environments, but environment has at least some control over the outcome (Macko \& Tyszka, 2009). Thus, an entrepreneur would consider to take risk by referring to their consent. In addition, once someone is interested in entrepreneurial field, she/he need to have willingness in risk-taking. This is because entrepreneur dealt with unforeseen contingency.

Based on study by Bakar et al. (2016), the researcher found that entrepreneurs are reluctant to take high risk and try to minimize it as possible in seize existing opportunities as the entrepreneur is in the medium category. Somehow, the entrepreneurs see challenges and obstacles as their opportunity to success in business and life. It is impossible for an entrepreneur to be successful in their field if they are running away from risk taking. By any means, the entrepreneur should face it or accept the risk so that this can show that they are ready to develop new inventions or innovation. Risk is an obligation that entrepreneur must bear and it should not be avoided in order to gain profit.

\section{Successfulness of Youth Entrepreneurship}

The essence of having successful business start-ups among the youth is to ensure that youth are not only employed, but have sufficient income to sustain their livelihoods, and also contribute to economic development of their nation (Simpson \& Christensen, 2009). Fostering youth entrepreneurship is key policy option for most developing countries. Globally, youth between 15 and 24 years make up $17 \%$ of the world population Carolyne (2016). So that this section explains on the successfulness of youth entrepreneurship. Entrepreneurship is one of the major contributors to economic growth. Being an entrepreneur is one of the easier job to do because they can generate some income even if the capital is little. Entrepreneurship as define by Stevenson and Jarillo (2009), is a process where the persons pursue opportunities without regard the resources that currently they are controlling. Entrepreneurship also being defines as a process of creating something that is new and predicting the risks and rewards (Hisrich \& Peters, 1998; Kinicki, 2003). Sexton and Bowman (1991) defines entrepreneurship as the process of recognizing opportunities, gather up the resources and exploited those opportunities through action.

Being an entrepreneur is a common thing in Malaysia especially among the youth. Nowadays, the young generation, especially the youth make up of $43 \%$ of the population in Malaysia. Their involvement in entrepreneurship has become the major topic among the educators, policy makers and students in most of the developing countries (Hidayah et al., 2013). The involvement of Malaysian in entrepreneurship has increasing. There are a lot of participants age under 40 years old unexpectedly had joined in the entrepreneurship and this can be considering as young entrepreneurship (Ridzwan et al., 2017). Entrepreneurship is one of the important driver of the country economic growth and social well-being, other than creating jobs for either for the unemployed person, or to the person who wants to make business as a second jobs. Even a small business can contribute to our country's economy. Many of the researchers agreed that the contribution to the economic growth is the entrepreneurial activities.

For the past years, we can see that the field of entrepreneurship has growth rapidly all around the world. The advancement of technologies has made us become easier to do business, either locally or internationally. Most of the young entrepreneurships starting to join in this field is 
Volume 3 Issue 8 (June 2021) PP. 01-21

DOI 10.35631/AIJBES.38001

because they can create their own values and they will be providing with their dream and can turn into reality (Ridzwan et al., 2017). A study done by Hidayah et al. (2014) showed that, young entrepreneur can be classified into three important stages which are teenagers the average age between fifteen to nineteen years' old which is called pre-entrepreneurs, the budding entrepreneurs that range between twenty to twenty-five years old and the emergent entrepreneurs whose are between the age of twenty-six to thirty-five years old.

A study shown that young individuals and their involvement in entrepreneurship has been increasing and the relevancy is because of the declining in the economy for the recent years (Brixiova et. al, 2015; European Commission, 2012; Minola et al., 2016; O’higgins, 2012; Rojas \& Siga, 2009; Thomas, 2009). More young people joining in the entrepreneurial sector because they can work freely on their own. They would not be bound to follow the instruction from their employers. Youth nowadays have been trained better in general in compared to the previous generation. Thus, this has made them become more capable, for example to start up and manage their own business (Honjo, 2004).

The government is trying to increase the number of successful young entrepreneurs so that it would reduce the number of unemployment and can increase the economic growth of the country. Among the necessary support that the government provides to these entrepreneurs are the development of old and new products and the improvement of technologies. Other than that, the government also introduced MARA, MARDI, FRIM and other government authorized agents in order to help the entrepreneurs (Kamal et. al., 2013). Haron (2010) found that only $20 \%$ of young entrepreneurs who are survived and success in the market for every year. This proves that the success rate among the youth entrepreneurs are still low in Malaysia. The success of youth in entrepreneurship may come from some factors such as business plan, business support program and risk-taking by entrepreneur. All the factors may contribute to youth start-up business. The first factor is business plan. According to Singhvi (2000) which had done a study on 24 small businesses along with their business plans, the researcher found that more than $70 \%$ of the business plan were used for financing. This can refer that business plan is important especially for financial. In order to start up business, once must have capital. Report by Streubing (1997) stated that a study conduct by American Institutes of Small Business found that the chances of success by the companies that undertaking major development or those companies that are starting new business would increase by $50 \%$ or more if they prepared the business plan first. Some of the entrepreneurships use the business plan to secure their funding.

Besides, the one that contribute to success of youth entrepreneur is business support program. As known, business support program can be financially and non-financially. The most influential that can affect the business is financial. According to Hambali (2011), the fund from government include grant, loans, equity, and capital that provide for the entrepreneurs. Apart from that, government also provide industrial training which government allocated RM87.4 million to buy training equipment to help the entrepreneur get the non- financial support. This show that it is important for entrepreneur to get the support in order to support their business unless the entrepreneur stable enough. The last factors contribute to success of youth entrepreneurs is the risk-taking. In order to be a successful entrepreneur, the most important element is risk-taking. This is because entrepreneur perceived to be more challenging in their job scope than normal employee that being paid in their daily life. Based on study conducted 
Volume 3 Issue 8 (June 2021) PP. 01-21 DOI 10.35631/AIJBES.38001

by Omar (2012) the result of the research shown that the highest pointer is risk taking that become the preferences in order for the young entrepreneur to success in business. Botha \& Robertson (2014) conclude that successful entrepreneurs are those who able to manage risk because financial management and the ability of working capital can influence the positive outcome. Figure 1 presents the conceptual framework which states that the youth entrepreneurship has connection with the three independent variable which are business plan, business support program and risk-taking.

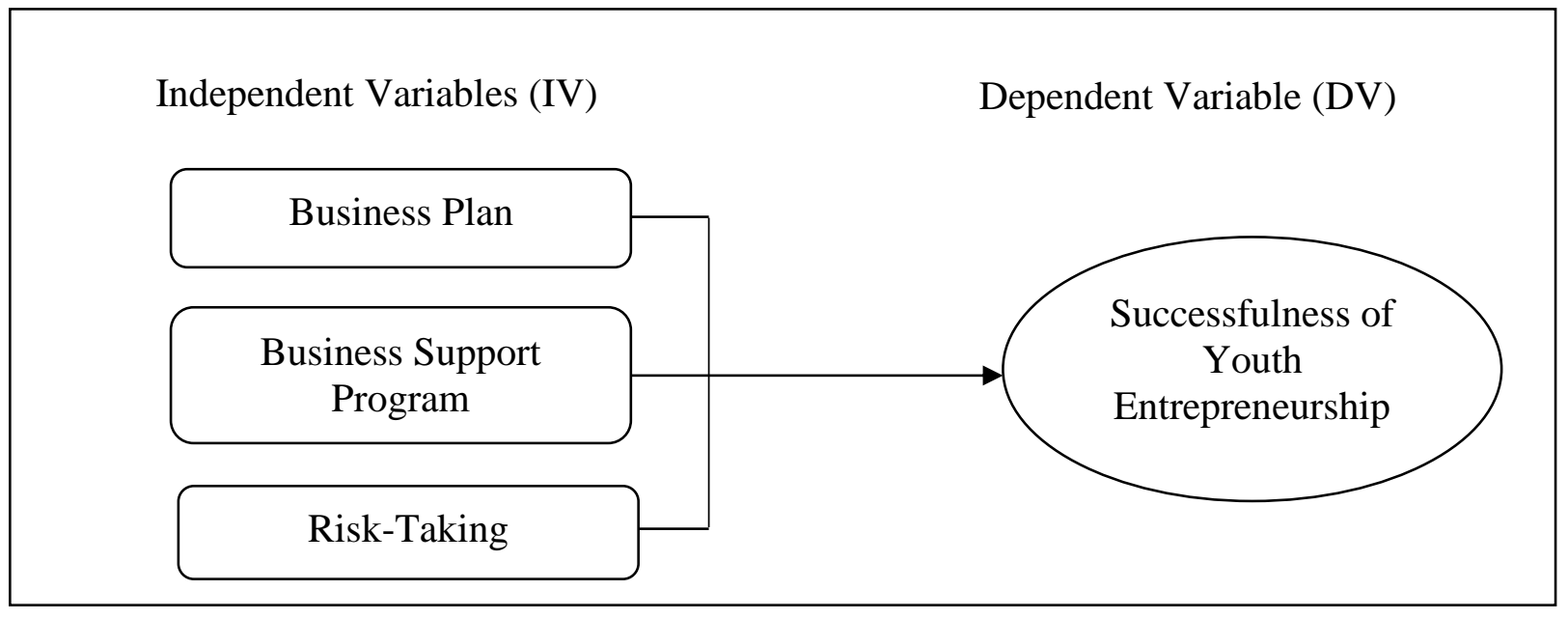

Figure 1: Conceptual Framework Factors in Contributing to The Youth Successfulness in Entrepreneurship

\section{Research Methodology}

In this study, the unit of analysis is youth. It focusses on the youth who are involving in the entrepreneurship.

\section{Research Design}

According to Agnes (2016), research design is a general outline about how to answer the research questions. A research design is use to make sure that the evidences acquires will be enable to answer the primary question as to be not open to more than one interpretation as possible. As a result of that, the research problem will be describing effectively (de Vaus, 2001). Research design constitutes the blueprint for collection, measurement and analysis of the data. This study will be using cross-sectional. This is because the data been collected at one time only. It is a one-shot survey from of the respondents. The cross-sectional would allow the researcher to compare with varieties of variables at one time. For example, it can be look at age, gender, educational level in relation to the successfulness of youth in entrepreneurship.

\section{Unit of Analysis}

Unit of analysis refers to the level of major entity that is emphasize in the study. To be more specific, it is the "who" or "what" are being analyze in the study. The unit of analysis could be the individuals for example students, teachers, manager and so on. Other than that unit of analysis also can be the organization (department or firm) and things such as pets, cars or places. It is important to determine the unit of analysis of the study in order to avoid confusion to the readers and the researcher. As this study is about the factors that contribute to the 
Volume 3 Issue 8 (June 2021) PP. 01-21 DOI 10.35631/AIJBES.38001

successfulness of youth in the entrepreneurship, the unit of analysis is the individuals which is the youth. It focusses on the youth who are involving in the entrepreneurship.

\section{Sample Size}

Sample means a group of people, items or objects that are taken from the population for the measurement. The sample would be the representative of all the population in order to make sure that it can be make general and broad statement from the sample of the study to the population as a whole. Sample size is the number of observations that is used for calculating the approximation of the population.

\section{Population}

Maina (2016) cited from Cooper and Schindler (2014) that population can be described as the whole collection of elements on what the researcher wants to make inference. For this study, the target population is in Seremban, a town and the capital of Negeri Sembilan. According to City Population, the population of the youth age between 20-30 years old in Seremban is 109 510 people (Department of Statistic, 2017). However, there is no accurate population of youth that become entrepreneurs. Therefore, this research used Roscoe (1975) which proposed a number of rules of thumb that can be used to select an appropriate sample for behavioral research. The sample suggest by Roscoe within 30-500 respondents. Thus 200 respondents which having business are selected to be in this research.

\section{Sampling Technique}

A sampling technique is the name for a specific process whereby the units of the sample has been identified. Sampling techniques can be divide into two categories which are Probability Sampling and Non-Probability Sampling. Probability Sampling is where the sample know the probability of he or she will be chosen while for Non-Probability Sampling is where the sample do not know about the probability to be selected.

This study chooses the Non-Probability Sampling because the element of the population does not have probability to be chosen as the sample subject for the study. One of the techniques under the sampling is Convenience Sampling. By using the technique, members of the target population that meet certain practical criteria such as available at a given time, easy accessibility, geographical proximity, or the willingness to participate are included for the purpose of the study. It also referred to the easily accessibility of researching subjects of the population by the researcher. Further, the target population for this study are the youth that having a business within few areas in Seremban.

\section{Measurement}

Trochim (2006) defined measurement as a process of observing and recording of that observations that are collected as part of the research effort. Only the observable representation of the concepts can be measured. This is why it is important to well define the identified concepts in the conceptual framework and understood the operational procedures. In this study, it is to determine the contribution factors, which are business plan, business support program, and risk taking would give effect of successfulness of the youth in entrepreneurship. A set of questionnaire has been distributed in order to get their feedback based on the variables in this study. 
Volume 3 Issue 8 (June 2021) PP. 01-21 DOI 10.35631/AIJBES.38001

Questionnaire is a set of printed or written questions with several choices of answers, used for the purpose of getting survey or for statistical study. It is used to collect information from the respondents. The questionnaire of this study are set in dual language, which are Malay and English language. The questionnaire divided into five sections, which are Part $\mathrm{A}$ is Demographic Data of Respondent, Part B is Business plan, Part C is Business Support Program, Part D is Risk Taking and Part E is Successfulness of Youth in Entrepreneurship Program.

\section{Finding \& Discussion}

\section{Demographic Profile}

The main objective for descriptive analysis is to understand the profile of the respondent. Based on the sample collected through the distribution of questionnaires to youth that having a business both by hand and online it shows no missing value. In this study, there are a total of $138(69.0 \%)$ female respondents and $62(31.0 \%)$ male respondents. The percentage shows that the composition of female respondents is much higher than the male. The highest of the respondents are from the age group 22 until 24 years with 84 respondents (42.0\%), followed by 28 until 30 years, 43 respondents $(21.5 \%)$. The minority of the respondents are from the age group of 25 until 27 years with 36 respondents (18.0\%), whereas 19 until 21 years, 27 respondents $(13.5 \%)$ and the least was from $15-18$ years with 10 respondents $(5.0 \%)$. There are four ethnic groups: Malays, Chinese, Indian and others. Malays respondents comprise the majority of the respondents contributing about $78.5 \%$ (157 respondents). The Chinese, Indian and others races group are the minority with $12.0 \%$ (24 respondents), $8.5 \%$ (17 respondents) and $1.0 \%$ (2 respondents) respectively.

The majority of the respondents are from Bachelor Degree holders with 91 respondents $(45.5 \%)$ and followed by Diploma holders' respondents with 60 respondents representing $30.0 \%$. The third ranked with 33 respondents representing $16.5 \%$ is SPM level. The minority of the respondents comes from Matriculation or Foundation and others, which each contribute 11 respondents $(5.5 \%)$, and 5 respondents amounting to $2.5 \%$. Most of the respondent answer for others for their type of business. Some examples for other type of business are such services, gadget, printing, cosmetics and so forth. This type of business contributes the highest respondent which is 82 respondent or $41.0 \%$. The apparels, and food and beverages both contributed slightly different percentage that is $23.0 \%$ and $22.5 \%$ with having number of respondents, 47 respondents and 46 respondents. However, handicraft contribute the least number of respondents, which is 26 respondents $(13.0 \%)$. Most of the respondent do not register their business with Suruhanjaya Syarikat Malaysia since the highest number of respondents comes from No answer is 145 respondent representing $72.5 \%$ while the remaining of 55 respondents $(22.5 \%)$ choose for Yes. The majority of the respondent earned profit between RM 301 and above with 107 respondents (53.5\%). This followed by respondents earned profit from RM 101 - RM 200, 43 respondents (21.5\%). The minority group that received profit per month for RM 10 - RM 100 and RM 200 - RM 300 is 30 respondents $(15.0 \%)$ and 20 respondents $(10.0 \%)$. The highest number of respondent operated their business comes from 0-1 year with 56 respondents (28.0\%). The second highest respondent is from 2-3 years contributed about 49 respondents representing $24.5 \%$. The third highest business duration contributed by $1-2$ years with 43 respondents $(21.5 \%)$. Both 3-4 years and 4 years above falls under minority group when the respondents only 27 respondents and 25 respondents with $13.5 \%$ and $12.5 \%$. 
In this study, there are a total of $138(69.0 \%)$ female respondents and $62(31.0 \%)$ male respondents. The percentage shows that the composition of female respondents is much higher than the male. As for the age of the respondents, the highest are from the age group 22 until 24 years with 84 respondents $(42.0 \%)$, and the least was from 15-18 years with 10 respondents $(5.0 \%)$. There are four ethnic groups: Malays, Chinese, Indian and others. Malays respondents comprise the majority of the respondents contributing about $78.5 \%$ (157 respondents). Others races such Sigh and Kadazandusun known as the minority group which only have $1.0 \%$ (2 respondents) respectively.

The majority of the respondents are from Bachelor Degree holders with 91 respondents (45.5\%) The minority of the respondents comes from others (PMR) only contributed 5 respondents amounting to $2.5 \%$. Besides, the youth entrepreneurs most involved in option “others' that refer to services, gadget, printing, and cosmetics. This type of business contributes the highest respondent which is 82 respondent or $41.0 \%$. However, handicraft contribute the least number of respondents, which is 26 respondents (13.0\%). Most of the respondent do not register their business with SSM since the highest number of respondents comes from No answer is 145 respondent representing $72.5 \%$ while the remaining of 55 respondents $(22.5 \%)$ choose for Yes. Out of 200 respondents, 107 respondents (53.5\%) of them earned profit between RM 301 and above. Meanwhile, 20 respondents (10.0\%) only earned profit between RM 200 - RM 300. The highest number of respondent operated their business comes from 01 year with 56 respondents $(28.0 \%) .4$ years and above falls under least respondents when only 25 respondents with $12.5 \%$.

\section{Reliability Test}

The rationale of having reliability test method is to check for a scale internal consistency. It concerned whether a scale indicates that it is free from random error. Apart from that, the reliability of a measures indicates the extent to which it is without bias by ensuring the consistent measurement across time and various items in the instrument. Therefore, the reliability of the scale instrument was tested through Cronbach's alpha coefficient test. According to Nunnally (1978) and DeVellis (2003) stated that the scale of variable ideally should at least meet a minimum level of 0.70 then only considered as high reliability. However, Nunnally (1967) stated that Cronbach's alpha coefficient of a scale still can be accepted if above 0.6. In this study, the Cronbach's alpha is set at 0.6. Therefore, from the test conducted this study found that all the variables have a Cronbach's alpha coefficient of more than 0.6. Table 1 show the summary of the reliability test.

Table 1: Summary of The Cronbach's Alpha of Each Variable

\begin{tabular}{|c|c|c|c|c|}
\hline Variables & & No. of items & $\begin{array}{l}\text { Cronbach's } \\
\text { Alpha Value }\end{array}$ & Decision \\
\hline Part B - Business Plan & & 8 & 0.795 & $\begin{array}{l}\text { Acceptable and } \\
\text { Moderate }\end{array}$ \\
\hline $\begin{array}{l}\text { Part C }- \text { Business } \\
\text { Program }\end{array}$ & Support & 8 & 0.808 & Good \\
\hline Part D - Risk-Taking & & 8 & 0.738 & $\begin{array}{l}\text { Acceptable and } \\
\text { Moderate }\end{array}$ \\
\hline
\end{tabular}


Volume 3 Issue 8 (June 2021) PP. 01-21 DOI 10.35631/AIJBES.38001

\begin{tabular}{llll}
\hline $\begin{array}{l}\text { Part E - Successfulness of Youth } \\
\text { in Entrepreneurship }\end{array}$ & 0.842 & Good
\end{tabular}

Source: Developed from SPSS output for this study

The findings of the reliability test on all the items in this study are consistent and reliable. The reliability tests support the appropriateness of the instrument that are used in this study and the concept is suitable in the area of the study.

\section{Normality Test}

The normality test is use to determine the sample size of distribution. The normality of the sample is construed from the values of skewness and kurtosis test. According to Coakes (2013), the Skewness and Kurtosis result is used to conduct for normality of the data where it will show the shape of distribution and used with rational and interval of the data. It is important to acknowledge that whether the sample collected falls within an appropriate range and it Skewness. Besides, study by Sekaran (2003), values of the Skewness should fall within the range of -2 to +2 while Kurtosis test must within -3 to +3 only considered the normal range. If the sample are not normally distributed, the technique of non-parametric will be used for further test, however if it is normally distributed the parametric technique will be used. Table 2 show the mean, standard deviation, skewness and kurtosis.

Table 2: The Mean, Standard Deviation, Skewness and Kurtosis of Each Item

\begin{tabular}{|c|c|c|c|c|c|c|c|}
\hline \multicolumn{8}{|c|}{ Descriptive Statistics } \\
\hline & \multirow{2}{*}{$\begin{array}{l}\mathrm{N} \\
\text { Statistic }\end{array}$} & \multirow{2}{*}{$\begin{array}{l}\text { Mean } \\
\text { Statistic }\end{array}$} & \multirow{2}{*}{$\begin{array}{l}\begin{array}{l}\text { Std. } \\
\text { Deviation }\end{array} \\
\text { Statistic }\end{array}$} & \multicolumn{2}{|c|}{ Skewness } & \multicolumn{2}{|l|}{ Kurtosis } \\
\hline & & & & $\begin{array}{l}\text { Statis } \\
\text { tic }\end{array}$ & $\begin{array}{l}\text { Std. } \\
\text { Error }\end{array}$ & Statistic & $\begin{array}{l}\text { Std. } \\
\text { Error }\end{array}$ \\
\hline Business_Plan & 200 & 3.6631 & .56087 & .171 & .172 & -.144 & .342 \\
\hline $\begin{array}{l}\text { Business_Support } \\
\text { Program }\end{array}$ & 200 & 3.5700 & .57380 & -.414 & .172 & 1.634 & .342 \\
\hline Risk_Taking & 200 & 3.7900 & .50822 & -.023 & .172 & 1.824 & .342 \\
\hline $\begin{array}{l}\text { Successfulness } \\
\text { Factor }\end{array}$ & 200 & 3.8264 & .59099 & -.178 & .172 & .290 & .342 \\
\hline Valid N (listwise) & 200 & & & & & & \\
\hline
\end{tabular}

Source: Developed from SPSS output for this study

Based on the Table 2, the highest mean among the variable is 3.8264 which is Factors contribute to Successfulness of Youth in Entrepreneurship while the lowest mean value is 3.5700 that is Business Support Program variable.

For the first independent variable which is Business Plan, the value of skewness is 0.171 which is positively skewed as it skews to the right (Skewness $>0$ ) while kurtosis values fall at -0.144 which showed low degree of peaked (Kurtosis $<0$ ). Therefore, this variable is in the normal range of distribution. 
Volume 3 Issue 8 (June 2021) PP. 01-21

DOI 10.35631/AIJBES.38001

The second variable, Business Support Program show the reading of skewness -0.414 which is negatively skewed (Skewness $<0$ ) and Kurtosis values are in the range of -3 to +3 which is 1.634 (kurtosis $>0$ ), therefore this variable is in the normal range of distribution.

The third variable is Risk Taking with the reading of -0.023 skewness which skewed negatively to the left (skewness $<0$ ) and having positive kurtosis values of 1.824 which fall between -3 to +3 . Therefore, this variable is in the normal range of distribution.

The last variable in this study is Factors contribute to Successfulness of Youth in Entrepreneurship which has a value of skewness -0.178 that negatively skewed to the left (skewness < 0) while kurtosis value is 0.290 (kurtosis > 0 ). Therefore, this variable is in the normal range of distribution.

According to the data for skewness and kurtosis value, both shows that all the items are within the range of normal distribution: therefore, parametric method will be used for the next analysis.

\section{Correlation Analysis}

As the collected data are normally distributed, the parametric statistic techniques is used. The purpose of using correlation analysis is to determine the route and the strength of linear relationship between two variables. A study by Pallant (2011) stated that a measurement level and nature of the data depend on each other where there are a number of dissimilar statistics that obtained in the SPSS. Besides, this been supported by a study of Goes (2011) where the relationship of the variables will be given a degree and a direction through statistical analysis in which the degree is determine on how closely the variables are being related. Thus, the related pairs, scale of measurement, normality, linearity and homoscedasticity are among the five assumption that need to be fulfilled in order to run the correlation analysis.

The first assumption referring to related pairs. This mean that the data collected must come from the related pairs where the respondents of the study should be the same sample of the same population (Coakes, 2013). In other words, the data from related pairs must achieved from same participation such if the score obtained from $\mathrm{X}$, then the score from $\mathrm{Y}$ is obtained from same participant. By referring to this study, there are 200 of respondents which classified as youth that having a business that comes from Seremban area. To justify this sample, the researcher reached the respondents by distributing to youth only.

The second assumption is scale measurement. According to Coakes (2013) the data must be in ratio or interval in nature. In this study, all the variables are computed in accordance to its own named and variables such as the Total of Business Support Program, The Total of Business plan and The Total of Risk Taking.

Aside from Scale Measurement, the third assumption is the normality test. According to Pallant (2007), normality is describing by a symmetrical bell shaped curved which having the greatest frequency of scores in the middle, with smaller frequencies towards the extreme. In this study, there are is no extreme outliers found and the values fell between the normal range after this was tested with normality test. Hence, the total sample size remained $N=200$. 
Volume 3 Issue 8 (June 2021) PP. 01-21

DOI 10.35631/AIJBES.38001

Next, linearity is one of the assumptions needed to be fulfilled. The relationship between two variables have to be linear. And last assumption is homoscedasticity where it has been defined where the variable is roughly the same for all values for other variables. In this study the dots are positively linear. As shown in the appendix.

In the relation to this study, Pearson's correlation is employed in order to examine the relationship between the independent variables (IVs) and dependent variable (DV). Hence, to test the relationship the mediator in this study is treated as dependent variable. Correlation coefficients are able to provide a numerical overview of the direction and strength of the linear relationship between IVs and DV. The Pearson correlation coefficients (r) range from -1 to +1 for indication of positive or negative correlation. The p-value should be less than 0.05 for the purpose in recognizing the level of significant between two continuous variables. Furthermore, the r-value also used to determine either the relationship between the variables is strong, medium or low correlation. In order to determine the strength of the relationship of the variables, the Guildford Rule of Thumb is used to describe the correlation.

Table 3: Guildford Rule of Thumb

R Value Strength of Relationship

$<.2$

$.2-.4$

$.4-.7$

$.7-.9$

$>.9$
Negligible relationship

Low relationship

Moderate relationship

High relationship

Very high relationship

Source: Developed from SPSS output for this study

The findings of the correlation between the independent variables and the dependent variables according to this study are summarized and presented in the Table 4.

Table 4: The Correlation Between the Independent Variables and Dependent Variable $(\mathbf{N}=\mathbf{2 0 0})$

\begin{tabular}{|l|l|l|l|l|l|}
\hline \multicolumn{2}{|l|}{ Correlations } & $\begin{array}{l}\text { Successfulness } \\
\text { Factors }\end{array}$ & $\begin{array}{l}\text { Business } \\
\text { Plan }\end{array}$ & $\begin{array}{l}\text { Business } \\
\text { Support } \\
\text { Program }\end{array}$ & $\begin{array}{l}\text { Risk } \\
\text { Taking }\end{array}$ \\
\hline $\begin{array}{l}\text { Successfulness } \\
\text { Factors }\end{array}$ & $\begin{array}{l}\text { Pearson } \\
\text { Correlation }\end{array}$ & 1 & $.579^{* *}$ & $.578^{* *}$ & $.488^{* *}$ \\
& $\begin{array}{lllll}\text { Sig. } \\
\text { tailed) }\end{array}$ & & & & \\
\cline { 2 - 7 } & $\mathrm{N}$ & 200 & 200 & 200 & .000 \\
\hline
\end{tabular}


Volume 3 Issue 8 (June 2021) PP. 01-21 DOI 10.35631/AIJBES.38001

\begin{tabular}{|c|c|c|c|c|c|}
\hline \multirow[t]{3}{*}{ Business Plan } & $\begin{array}{l}\text { Pearson } \\
\text { Correlation }\end{array}$ & $.579^{* * *}$ & 1 & $.411^{* *}$ & $329^{* * *}$ \\
\hline & $\begin{array}{l}\text { Sig. } \\
\text { tailed })\end{array}$ & .000 & & .000 & .000 \\
\hline & $\mathrm{N}$ & 200 & 200 & 200 & 200 \\
\hline \multirow[t]{3}{*}{$\begin{array}{l}\text { Business Support } \\
\text { Program }\end{array}$} & $\begin{array}{l}\text { Pearson } \\
\text { Correlation }\end{array}$ & $.578^{* * *}$ & $411^{* * *}$ & 1 & $213^{* *}$ \\
\hline & $\begin{array}{l}\text { Sig. } \\
\text { tailed })\end{array}$ & .000 & .000 & & .002 \\
\hline & $\widehat{\mathrm{N}}$ & 200 & 200 & 200 & 200 \\
\hline \multirow[t]{3}{*}{ Risk Taking } & \begin{tabular}{|l} 
Pearson \\
Correlation
\end{tabular} & $488^{* * *}$ & $329^{* *}$ & $213^{* *}$ & 1 \\
\hline & $\begin{array}{l}\text { Sig. } \\
\text { tailed })\end{array}$ & .000 & .000 & .002 & \\
\hline & $\mathrm{N}$ & 200 & 200 & 200 & 200 \\
\hline
\end{tabular}

Source: Developed from SPSS output for this study

\section{Hypothesis Testing}

\section{Hypothesis (1) on Business Plan and the Successfulness of Youth in} Entrepreneurship

$\mathrm{H}_{1}=$ There is a positive relationship between the business plan and successfulness of youth in entrepreneurship.

Table 5: The Relationship Between Business Plan and the Successfulness of Youth in Entrepreneurship

\begin{tabular}{lll}
\hline Independent Variables & Person Correlation (r) & Sig \\
\hline Business Plan & 0.579 & 0.000
\end{tabular}

Source: Developed from SPSS output for this study

Based on the table above, there is a relationship between business plan and the successfulness of youth in entrepreneurship where, $r=0.579$ and $p=0.000(p<0.005)$. This mean the hypothesis is accepted.

\section{Hypothesis (2) on Business Support Program and the Successfulness of Youth in Entrepreneurship}

$\mathrm{H}_{2}=$ There is a positive relationship between the business support program and successfulness of youth in entrepreneurship. 
Volume 3 Issue 8 (June 2021) PP. 01-21 DOI 10.35631/AIJBES.38001

Table 6: The Relationship Between Business Support Program and the Successfulness of Youth in Entrepreneurship

Independent Variables $\quad$ Person Correlation (r) Sig

Business Support

$\begin{array}{lll}\text { Program } & 0.578 & 0.000\end{array}$

Source: Developed from SPSS output for this study

Based on the table above, there is a relationship between business plan and the successfulness of youth in entrepreneurship where, $r=0.578$ and $p=0.000(p<0.05)$. This mean the hypothesis is accepted.

Hypothesis (3) on Risk Taking and the Successfulness of Youth in Entrepreneurship $\mathrm{H}_{3}=$ There is a positive relationship between the risk taking and successfulness of youth in entrepreneurship.

Table 7: The relationship between Risk Taking and the Successfulness of Youth in Entrepreneurship

\begin{tabular}{lll}
\hline Independent Variables & Person Correlation (r) & Sig \\
\hline Risk taking & 0.488 & 0.000 \\
\hline
\end{tabular}

Source: Developed from SPSS output for this study

Based on the table above, there is a relationship between risk taking and the successfulness of youth in entrepreneurship where, $r=0.488$ and $p=0.000(p<0.05)$. This mean the hypothesis is accepted.

Hypothesis on Business Support Program hold the most influential component towards the Successfulness of Youth Entrepreneurship

By referring to the Table 8, the largest standardized coefficient beta is 0.381 which is contributed by Business Support Program, followed by the Business Plan, which has a beta coefficient of 0.324 and the lowest was Risk taking having 0.300 beta coefficient. This indicates that Business Support Program have a stronger unique contribution in explaining the dependent variables compare to another two variables. All the three variables have significant values of is $p=0.000$ which is $p<0.005$. The $B$ value is an indication to predict the dependent variables values and significant values have less than $0.005(\mathrm{p}<0.005)$ is significant. 
Volume 3 Issue 8 (June 2021) PP. 01-21 DOI 10.35631/AIJBES.38001

Table 8: Coefficient of Dependent Variable

\begin{tabular}{|c|c|c|c|c|c|c|}
\hline \multicolumn{7}{|c|}{ Coefficients } \\
\hline & & \multicolumn{2}{|c|}{\begin{tabular}{|l} 
Unstandardized \\
Coefficients \\
\end{tabular}} & \multirow{2}{*}{\begin{tabular}{|l|l}
$\begin{array}{l}\text { Standardized } \\
\text { Coefficients }\end{array}$ \\
Beta \\
\end{tabular}} & \multirow[b]{2}{*}{ t } & \multirow[b]{2}{*}{ Sig. } \\
\hline \multicolumn{2}{|c|}{ Model } & $\mathrm{B}$ & Std. Error & & & \\
\hline \multirow[t]{4}{*}{1} & (Constant) & -.146 & .263 & & -.557 & .578 \\
\hline & Business plan & .341 & .057 & .324 & 5.956 & .000 \\
\hline & $\begin{array}{l}\text { Business Support } \\
\text { Program }\end{array}$ & .392 & .054 & .381 & 7.249 & .000 \\
\hline & Risk Taking & .349 & .059 & .300 & 5.914 & .000 \\
\hline
\end{tabular}

a. Dependent Variable: Successfulness Factors

Source: Developed from SPSS output for this study.

Therefore, Hypothesis on Business Support Program hold the most influential component towards the Successfulness of Youth Entrepreneurship is supported with the data above. More ever, some of the factors that could lead effectiveness of the youth in entrepreneurship are business plan, business support program and risk taking. Certain scholars agreed that having business plan that lead the entrepreneurs to be successful in their business while certain scholars cannot found how the business plan can make entrepreneurs to be successful. Each scholar has their own reasons on why business plan is one of the factor that can or cannot lead the successfulness of a youth in entrepreneurship. For example, Delmar and Shane (2003) as cited in Ferreira et al. (2016) found that there are many positive effects from the business plan that stress on the speed in decision making, the expectation on business weakness, and the improvement of communication internal and external to business. However, Delmar and Shane (2003) along with Chandler et al. (2011) stated that there is a debate about the value of business plan in the entrepreneurship field. The test has been carried out in order to identify the relationship between business plan, business support program, and risk taking with successfulness of youth in entrepreneurship among youth. Based on finding, factors such as business plan, business support program, and risk taking, the study revealed that all these factors have relationship with successfulness of youth in entrepreneurship among youth.

The government also should have given business support program to the entrepreneurs, moreover to those whose are new to their businesses. With the support program, the youth entrepreneurs would know how to handle their businesses. Example of support program that can be given to the youth entrepreneurs are advising on the business, training, improving the business and so on. In order to make sure that the support programs can meet the satisfaction of the entrepreneurs, the policy makers and programs administrator have to measure satisfaction of business support program through the impact on performance, growth in sales, employment and profitability (Mohd Khan et. al., 2016). Most researchers found that business support programs help the entrepreneurs a lot in making their business successful.

\section{Conclusion}

As a conclusion, the issues or problems of unemployment in the local economy amidst current uncertainties in global market demand and economic crisis situations have led to the need for any society at large to find opportunities in self-employment, including by the youths. Due to that our government always introduced programs and policy in order to reduce unemployment 
Volume 3 Issue 8 (June 2021) PP. 01-21 DOI 10.35631/AIJBES.38001

rate especially among youth with entrepreneurship programs. The findings of this study may contribute to providing factors that contribute to the successfulness of youth entrepreneur in entrepreneurship and can increase youth participation and involvement in entrepreneurship as a form of career path. It also hoped that this study should continue and wider the research area and with inclusion of others variables so that all the factors can be suggested for new entrepreneurs to start business and same goes to the current entrepreneurs for them to enhance their business. It is particularly important for entrepreneurs to possess the factors because without having none of the factors that has been studied, it is difficult for them to step ahead.

\section{References}

Agnes, A. S. (2016). Factors Influencing Participation of Youth in Entrepreneurship in Kenya: A Case of Youth Entrepreneurs in Kakamega Central District, Kakamega County. 157.

Agusmiati, Ramli, A., \& Abdul Latief, D. (2018). The Relationship between the Performance of Women Entrepreneurs in Acheh: The Moderator Business Environment. Journal of Global Business and Social Entrepreneurship (GBSE), 21-31.

Ahmad, S., \& Abd Latif, I. (2012). The Effectiveness of Public Advisory Services: What are the Important Factors? International Journal of Business and Management, 19-30.

Aman Allah, M., \& Nakhaei, H. (2011). Entrepreneurship and risk - taking. International Conference on E-business, Management and Economics, 77-79.

Bakar, N., Samad, M., Awaludin, N., Jaafar, S., \& Nadzri, S. (2016). Kajian Faktor Penglibatan Belia dalam Keusahawanan. Proceeding of the 3rd International Conference on Management \& Muamalah 2016 (3rd ICoMM), 172-181.

Bandera, C., Passerini, K., \& Collins, R. (2018). Risky business: Experiential learning, information and communications technology, and risk-taking attitudes in entrepreneurship education. The International Journal of Management Education, 225238.

Becherer, R., \& Helms, M. (2009). The Value of Business Plans for New Ventures: Company and Entrepreneur Outcomes. Journal of Small Business Strategy, 81-96.

Brixiova, Z., Ncube, M., \& Bicaba, Z. (2015). Skills and youth entrepreneurship in Africa: Analysis with Evidence from Swaziland. World Development, 11-26.

Brockhaus, R. H. (1980). Risk taking propensity of entrepreneurs. Academy of Management Journal, 509-520.

Carolyne W. Maina. (2016). Factors Influencing the Success of Youth Entrepreneurship Business Startups: A Case of Technoserve Stryde Program in Nyeri County. United States International University - Africa.

Chandler, G., DeTienne, D., McKevie, A., \& Mumford, T. (2011). Causation and effectuation processes: A validation study. Journal of Business Venturing, 375-390.

Chor, F. T. (2009). Perception Differential between Employers and Undergraduates on the. International Education Studies, 95105.

Cowling, M., \& Bygrave, W. (2003). Entrepreneurship and Unemployment: Relationships between Unemployment and Entrepreneurship in 37 Nations Participating in the Global Entrepreneurship Monitor (GEM). Entrepreneurship Research Conference (BKERC), 544-555.

Department of Statistic Malaysia. (2017, 12 30). Retrieved from Population in Seremban Negeri Sembilan: https://www.citypopulation.de/php/malaysiaadmin.php?adm2id=0505. 
Volume 3 Issue 8 (June 2021) PP. 01-21 DOI 10.35631/AIJBES.38001

Ferreira, A. M., Loiola, E., \& Gondim, S. G. (2016). Motivations, business planning, and risk management: entrepreneurship among university students. RAI Revista de Administração e Inovação, 141-150.

Haan, I. d. (2010). Characteristics of entrepreneurs and risk taking. Bachelor Thesis Organization and Strategy, 2-30.

Honig, S., \& Samuelsson, M. (2011). Business Planning and Venture Level Performance: Challenging The Institution of Planning. Sweedish Entrepreneurship Forum, 1-23.

Ismail, N. A. (2011). Graduates' Characteristics and Unemployment: A Study Among Malaysian Graduates. International Journal of Business and Social Science, 94-95.

Ismail, R., \& Othman, N. (July-December 2014). The effctiveness of Government-Support Programmes towards Business Growth. Journal of Technology Management and Technopreneurship, 41-52.

Joseph, J., \& Kuriakose, F. (2015). Nurturing Youth Entrepreneurship to Tackle Youth Unemployment: Journal of Research Innovation and Management Science, 5-11.

Kamal, C. P., Hamzah, A., Abu Samah, B., \& D'Silva, J. L. (2013). Rural Malay involvement in Malaysian herbal entrepreneurship. Asian Social Science, 202-208.

Karlsson, T., \& Honig, B. (2009). Judging A Business by Its Cover: An Institutional Perspective on New Ventures and The Business Plan. Journal of Business Venturing, 27-47.

Macko, A., \& Tyszka, T. (2009). Entrepreneurship and risk taking. Applied Psychology, 469487.

Minola, T., Criaco, G., \& Obschonka, M. (2015). Age, Culture, and Self-Employment Motivation. Small Business Economics, 187213.

Mohd Khan, S., Md Noor, N., \& Anuar, A. (2016). Performance of Youth Entrepreneurs in Malaysia Micro Small and Medium Enterprises. International Journal of Economics and Financial Issues, 86-91.

O'Higgins, N. (2012). This time it's different? Youth Labour Markets During 'The Great Recession'. Comparative Economic Studies.

Olugbola, S. A. (2017). Exploring Entrepreneurial readiness of youth and start-up success components: Entrepreneurship training as moderator. Journal of Innovation and Knowledge, 156-171.

Rahim, H. L., Abdul Kadir, M. A., Zainal Abidin, Z., Junid, J., Mohd Kamruddin, L., Mohd Laijin, N., Ahmad Bakri, A. (2015). Entrepreneurship Education in Malaysia: A Critical Review. Journal of Technology management and Business (ISSN:2289-7224), 11.

Ridzwan, R., Nik Muhammad, N., \& Ab Rahman, A. (2017). Issues and Challenges among Young Entrepreneurs in Malaysia. Journal of Business and Management, 80.

Rojas, G. V., \& Siga, L. (2011). On the nature of micro-entrepreneurship: evidence from Argentina. Applied Economics, 2667-2680.

Salleh, F., \& Ibrahim, M. (2011). Demographic Characteristics Differences of Risk Taking Propensity among. International Journal of Business and Social Science, 149-153.

Warman, S., Roddin, R., Esa, A., Awang, H., Mohamed, M., \& Ab. Rahman, A. (2010). Penerapan Kemahiran Keusahawanan Dalam Kalangan Pelajar di Politeknik. Persidangan Kebangsaan Pendidikan Kejuruteraan dan Keusahawanan, 206-211.

Yurtkoru, E., Acar, P., \& Teraman, B. S. (2014). Willingness to take risk and entrepreneurial intention of university students: An empirical study comparing private and state university. Journal of International Studies, 834-840. 
Volume 3 Issue 8 (June 2021) PP. 01-21 DOI 10.35631/AIJBES.38001

Yusoff, M., \& Yaacob, M. (September 2010). The Government Business Support Services in Malaysia: The Evolution and Challenges in New Economic Model. International Journal of Business and Management, 60-71.

Yusuf, J.-E. (2010). Meeting entrepreneurs' support needs: are assistance programs effective? Journal of Small Business and Enterprise Development, 294-3. 